BENITA SIMATI-KUMAR

\title{
The Potential of Vā Part 3: Location and Identity
}

\section{Abstract}

The article presented is part of a series of articles that composed an exegesis, submitted in fulfilment of the requirements for the degree of Doctor of Philosophy. The series is a narrative of discovery through practice-led research. Each article reveals its purpose and significance that leads into the next series, which then eventuate to that final design proposal.

The exegesis is presented in this format, to break down the components that assisted in practice-led research. Each article can be read and unpacked on its own as a learning tool. The purpose of this edited series is for the exegesis to be more accessible and adaptable creatively to those being introduced to practice-led research.

The Potential of Vā Part 3: Location and Identity, presents the findings from the research participants in relation to the research question, including the recurring themes from the participants' stories. As part of an exegesis-based thesis, this section 
presents selected photographic documentation of living spaces from the interviews. It then discusses the findings from the participant stories in relation to the literature and the research questions.

\section{Physical manifestations of identity}

This article presents findings from the interviews with the six participants on their experiences with blended identity and their own spaces of living. This discussion is in four parts, and the participants were asked the following research questions:

\section{Identity}

- What is your identity, how do you define yourself?

- What does diaspora mean to you? Do you associate with the term?

Sense of belonging

- Have you visited the islands that you are from? Have these visits influenced or changed your perspective and view of your identity?

The vā

- Which of the cultures that make up your blended identity do you affiliate with the most and why?

- Do you feel that a blended Pacific identity is acknowledged in your community? How?

Space

- Where in your daily life do you feel most connected to your identity? 
- How does your space/ home/ furniture/ garden/ art reflect you as a person? Does your environment reflect your blended identity?

- What comparisons can be drawn between the home you grew up in as a child and your home environment now?

- Where do you most feel 'at home' in terms of your identity?

\section{Part One: Identity}

Prior to explaining the term 'blended', I wanted to hear from each participant how defined themselves and their individual identity. Every talanoa drew closer to their identities and who they were, and so part one begins with a discussion about their identities. This is followed by their accounts of their individual explanations on defining themselves. Question one asked 'What is your identity, how do you define yourself?' Tasi said:

I am Pacific, I am a New Zealand born Pacific Islander of Sāmoan, Tongan but also Chinese descent. (Tasi 2015, personal communication)

Tasi acknowledged first that she is Pacific, but then confirmed that she was a New Zealand-born Pacific Islander, for Tasi it was important to mention this specific detail and note the difference between Pacific-born and New Zealand-born Pacific Islanders. Lua said: 
Firstly, I am a Mother, female, Pasifika, fiercely protective of my children, maternal. These attributes I accredit to my Mother. (Lua 2015, personal communication)

Lua acknowledged that her identity was that she is first and foremost a mother and female. Lua use the term Pasifika and credited her mother for her attributes of being very protective of her children. Tolu noted:

New Zealand/Kiwi/ Polynesian. (Tolu 2015, personal communication)

Tolu identified herself as New Zealand Polynesian and was the only participant who used the word Kiwi to define her identity. It spoke of her close connection to New Zealand and that it was very much a part of her identity. Fa said:

My identity I am half Sāmoan half Mãori. (Fa 2015, personal communication)

Fa defined her identity as one whole, half being Sāmoan and the other half Māori.

Lima said:

New Zealand Pacific. (Lima 2015, personal communication)

Lima was also simplistic in the way she defined her identity as New Zealand Pacific, that she wasn't just 
one or the other, but defined what type of Pacific identity she was by acknowledging she was a New Zealand Pacific. Ono said:

I describe myself as a 'woman of the Pacific; a Pacific woman; a woman from Polynesia; a Polynesian woman'. This is because my ethnicity spans several Polynesian islands including: Māori in Aotearoa; native Hawaiian from the island of Maui; Cook Island Māori from the northern Cooks of Penrhyn (Tongareva), Rakahanga and Manihiki and Sāmoa. (Ono 2015, personal communication)

Ono was the most descriptive when it came to defining her identity; she was passionate and spoke very poetically about who she is. Ono was specific about her lineage, and the Pacific Islands that made up her identity.

Most, if not all, of the female participants were brief and described themselves as either New ZealandPacific or Polynesian. Their individual response to the question refers to the 'new identity' (Spickard et al., 2002), that even though most were not native New Zealanders, they felt as if New Zealand had to be acknowledged as part of their Pacific identity, as if it would set them apart from other Pacific and Polynesian peoples.

Question two asked 'What does diaspora mean to you? Do you associate with the term?' As anticipated from the literature, most of the participants had vaguely heard the term diaspora, but did not 
describe themselves as diasporic identities. Therefore, as the researcher, I explained this term, and how it is used within this body of research. Of the six I interviewed, four knew the term but were brief in their reply, so their responses are discussed first. Those of the six who were more knowledgeable about the term diaspora are discussed next, followed by their views in relation to identity.

Tasi who earlier acknowledged that she was a New Zealand born Pacific Islander, didn't feel any affiliation with the term diaspora. She said:

Diaspora to me means widespread from our homelands. I have never really associated with this term before. (Tasi 2015, personal communication)

Tasi was clearly knew the term had to do with migration and leaving the homeland of the Pacific, but never associated with the term. This is also supported in Lima, and Tolu's response, who say:

I have heard of the term diaspora in literature, but I don't associate with it. (Lima 2015, personal communication)

Not a term I hear every day. To do with migration. (Tolu 2015, personal communication)

Their responses were brief but to the point. Lua added that it was an ancient Greek term she learned 
in school, then specified that it related to her parents who left the Pacific Islands for New Zealand seeking a better life. She went on to say:

From school I remember this to be an Ancient Greek term given to 'a scattering or sowing of seeds'... I don't really associate with the term, as it was my parents who left their Pasifika islands to come to New Zealand seeking a better life. I am NZ born and I have my connection to my ethnicity/heritage, but I don't feel that I am the one to feel being torn or pulled from my roots. (Lua 2015, personal communication)

Initially, Fa didn't think she was diaspora because of the notion with migration, but then took a long pause and reflected upon her own experiences as a New Zealand-born Sāmoa. She says/said:

I don't think I am diaspora because I was born in New Zealand, so I can't really relate to it in terms of migrating somewhere else, but I think it relates to me in being two different ethnicities. So the times when I go to Sāmoa, I can sort of feel a sense of belonging there but I live in New Zealand. But also living here in Porerua, which is a strong Pacific Island community and travelling to my mum and my Mãori family up North it's like a strong Māori community, to me it's like I got the best of both worlds I can relate in both culture's, as they are quite similar, but there not, like the values are similar. So 
diaspora I can relate to it, but I don't feel like it describes all of me and who I am. (Fa 2015, personal communication)

Fa's response was interesting as she redefined her use of the term to describe the experiences she felt visiting Sāmoa, and her Māori family north of Auckland city. To her, diaspora meant feeling a sense of belonging to places of identity, away from Porirua Wellington, where she lives. Ono's response to the question is similar however her use of the term is somewhat different again. She says/said:
I understand diaspora to mean any group or community that have fled their country of origin. I understand that the term is a Greek term and related originally to the scattering of the Jews to countries outside of Palestine after the Babylonian captivity. In modern times I understand the word to mean a scattered population with a common origin. Yes, I do associate with the term because my family has immigrated to Aotearoa from Hawai'i, Sāmoa and the Cook Islands and because I was born here in Aotearoa and not on any of the islands. (Ono 2015, personal communication)

It is evident in these participant responses that the use of the term diaspora is changing and has weakened for Pacific Islanders living in Aotearoa/New Zealand who are members of the second and third generations (Spickard et al., 2002). 
However, it is also important to realise that Fa and Ono have thought-provoking responses, as they were able to conceptualise the meaning of diaspora for themselves, in their own living context, and therefore able to relate to the term.

\section{Part two: Sense of Belonging}

When asked if the participants have visited the islands that they are from, and whether this had influenced or changed their identity, they each had a unique experience. Yet they all came to the realisation that they felt more closely connected to their Pacific identity. A sense of belonging had come through in the participant responses. Lua, in her interview, pointed out that although she felt a sense of belonging to Niue when she first visited at the age of 54, this did not change her sense of identity. It did, however, enrich her perspective of her native culture. Lua says:

Niue - this was totally a different connection all together. My first visit to Niue was in 2011 at 54 years' age. Leaving the airport and standing in the middle of the 'main road' two hours later - I felt and knew - this is where I belong...I absolutely loved the emotion and have been back several times to visit with family and enjoy The Rock...My visits have been a couple of weeks at a time as initially there was only one weekly flight to Niue. This has been improved with another service being provided. My visit to Niue did not change my identity - more so - it 
gave me a stronger insight as to where I belonged, where I/ my parents came from, what life may have been for them, why they left to come to New Zealand... It gave me a perspective of enrichment, a million and one questions to ask my Mum when I returned to NZ. (Lua 2015, personal communication)

Tasi's constant visits to Tonga meant that she felt more closely connected to her Tongan identity. She felt that if she were to visit Sāmoa and China as often, then she would have the same connections to these places as she does for Tonga. She said:

The more times I have visited Tonga, the closer connected I feel with my identity of being Tongan. I feel I also need to go back to Sāmoa so I can have the same connection there and I would also, one day, like to visit Guangdong province in China which is where the Chinese workers that first came to Sämoa come from. (Tasi 2015, personal communication)

Ono supported Tasi's statement but goes into detail and lists the factors that influenced her Pacific identity. She said:

Travelling to these islands has given me greater insight into the languages and cultures and enabled me to reflect upon my own upbringing, lifestyle, environment, behaviours and ways in which I interpret the world around me. So yes, 
these trips have influenced my identity over time. When I am in Hawai'i I feel more Hawaiian than Mãori. I used to feel more Mãori while living in Aotearoa, but as I have grown older, I feel a very strong mix of Pacific and Māori. (Ono 2015, personal communication)

The experience of visiting the islands was a real eye opener for the majority of these participants. Most indicated a sense of appreciation for the Islands, and they acknowledged the environment and lifestyle of the people, but at the same time were aware of the benefits they had growing up in New Zealand. Fa says:

I have been to Sämoa twice and both times I have stayed for three weeks. After the first time it was a real eye opener, because I guess you don't really appreciate what you have, until you go somewhere and your like..."the struggle is real".. (Laughs) and your crying because you didn't get a lolly. (Laughs) No but in all seriousness it was a good eye opener because it made me appreciate everything, but it made me understand sort of where they family in Sāmoa) were coming from in terms of money, what I really understood was because we were from New Zealand, and we were visiting Sämoa that we were seen as rich, because you lived in New Zealand, and things like that, and I got to understand that better because of the conversation I had with my nana. I asked my 
nana why don't you tell our family that we're not rich, that we're not millionaires that we can't pull money out of our pockets like left, right, and centre, for them. Like I understood that they were struggling but so are we, it's just like in a different way. In Sämoa they can grow their crops they have that freedom to work and sustain themselves of the land, but here in New Zealand we have to find work and jobs to survive. So that's what I mean that we are both struggling. Nana's response was that she agreed with me, she said that "they don't know because they have never left Sämoa, so what they see is that we are coming to the island with our flash clothes and assume that we are rich, they don't understand our story back in New Zealand. But then I wanted my nana to make them understand, because I was getting annoyed at our family always asking for money, money for this, money for that, like we are struggling to pay our bills, and I totally feel for them but at the end of the day, we are not rich ourselves, but then nana got me to understand things a lot better. In terms of appreciation I appreciated everything a lot more, just being able to drive around here in New Zealand, the food that we ate, the quality of things that we have, like health, education and other benefits. And seeing back in Sämoa that they had minimal things but were really happy, like not needing materialistic things to make you happy. The second time I went was 
with my little cousin, and it was good for him to see everything because he is quite spoilt so it was a good experience to see everything with him and value the life we had at home. The last time I was in the island was in 2009, I'm due to go back to the islands soon and take my husband back because he has never been, and he is full Sämoan. (Fa 2015, personal communication)

Fa expressed the view that 'they were seen as rich' coming from New Zealand, and that they were more fortunate, but the reality was they too were struggling to maintain their lifestyle. $\mathrm{Fa}$ summarised the hardship many Pacific migrants face when leaving the homeland to find better opportunities for their families in Western countries. She noted they are faced with new difficulties of maintaining their family and living expenses in Aotearoa/New Zealand, whilst supporting family back in the Pacific Islands. Such practices are encoded within fa'aSāmoa, where individuals are constantly reminded of the importance of their contributions to the collective welfare of the 'âiga. As mentioned, one develops one's 'āiga relationships through responsibilities that are maintained over time. Sāmoan society is highly stratified, and a person's status determines his or her roles, responsibilities and corresponding entitlements. (Howard et al., 2002; Tagoilelagi, 1995; Tuagalu, 2009). Fa's nana was merely upholding the values and teachings she grew up with and passing the 
knowledge of fa'aSāmoa onto Fa. Fa'aSāmoa encourages and obliges 'āiga to become cohesive, and fa'alavelave operates to ensure that 'āiga meet together often, with continuous open communication to and from New Zealand, the homeland and abroad (Anae, 1998a).

\section{Part three: The Vā}

We often talk about the vā as a conceptual relational space that is separate but connected. The vā was evident when the participants spoke about their blended identities, specifically in response to the question 'Which of the cultures that make up your blended identity do you affiliate with the most and why?' Most said in their experiences growing up, one culture had always played a dominant role over the other, and this was influenced by location, parents, elders in the family, language, and church. Fa said:

I affiliate most with my Sämoan side because I was raised in it, my Sämoan family is a lot bigger than my Mãori family, and actually where I live in Porerua, all my Māori family don't live there, they all live up North, and most of my Sämoan family live in Porerua with me. I go up North twice a year to see my Maori family, because me and my mum are really close and all my Maori family we are really close. I'm living with my dad at the moment because I'm trying to save for a house with my husband. (Fa 2015, personal communication) 
Being raised in the Sāmoan culture meant Fa was closely affiliated to her Sāmoan identity, and she added that this was also influenced by her location because she lived amongst most of her Sāmoan family. However, her location didn't mean her Māori identity was compromised; she remained closely connected to her mother of Māori decent and visited her Māori family as often as she could. For Lua her experience was much the same as Fa's, raised in her Niuean culture as it was dominant in her household growing up. She said:

I affiliate more with my Niue culture - although my Mother is Sämoan and my Father Niuean, my Mother was sent to Niue where she met and married my Father. Maybe because my Father was the head of the house - I don't know for sure, but I remember growing up that the main culture in our home was Niuean. My Niuean family visited all the time, our home was always filled with Niuean relatives and cousins. I remembered that my Sämoan family was very strict all the time - when growing up, I always felt that they were not much fun - therefore, I/ we gravitated to mainly our Niuean side. (Lua 2015, personal communication)

Lua expressed that her Sāmoan family was very strict, and reflecting on her response, it never occurred to me to ask Lua to elaborate on this topic. Lua's view of her Sāmoan family could have resulted from them being very strict in their fa'aSāmoa. It is 
important to note that perhaps Lua felt the paradox of identity that she was not 'Sāmoan enough', and didn't understand their ways of being (Anae, 1998a), therefore distancing herself and creating a vā. This point is further explored in Ono's response, who affiliated more with her New Zealand Māori, Cook Island Māori and Hawaiian identity, because the fa'aSāmoa way was denied by her Sāmoan grandmother, who broke tradition by refusing to marry a Sāmoan man. She states:

I affiliate more with New Zealand Māori, Cook Island Māori and Hawaiian. This is because my paternal grandmother was very close to her Cook Island father and fought with her Sämoan mother to the point where she defied her mother's wish for an arranged marriage to a Sämoan and eloped with her Hawaiian beau. She married for love. (Ono 2015, personal communication)

The vā, although not explicitly recognised by the participants, was present in their lives as being the space that separated them from the other cultures and traditions that made up their blended identities. This is not to say that it was intentionally disregarded, but it was something I recognised from my experience of vā, as more of a space that could be filled and nurtured. This then led me to ask each participant if they felt that blended identity was acknowledged in their community. Their responses were: 
All my life I have been made to separate out my Pacific side from my Māori side such as: the forms we fill in to go from primary to secondary school and on more official forms like the NZ Census. This also applies to the communities we belong to as a result of intermarriage being frowned upon. Often it was very hard as a child juggling the multiple identities associated with our mixed ethnicity and the pushback from peers and society in general on accepting thesea kind of clandestine racism. While this seems to have reduced to some extent as an adult it is alive and well in some quarters of my life and particularly in my work environment. Unusual though it may sound, haole colleagues perceive me as being only Māori and are in denial about my Pacific genealogical links. The same can be said for my Pacific colleagues who claim the same thing and go a step further by claiming that Māori are colonising the Pacific in Aotearoa/New Zealand. There is an attitude by some Pacific and Māori colleagues that if you are of 'mixed blood' then you are contaminated, or less than and don't count as being a Pacific person or a Māori person. It is very disturbing and so as a protection this can lead people from blended backgrounds to choose one identity over another. For me, I have NEVER chosen one over the other; throughout my whole life I have always been defiant and acknowledged all of my identities. Not to do so would have made me 
feel like an empty vessel. (Ono 2015, personal communication)

Ono spoke of the difficulties she experienced growing up in her community with her blended background, having to justify her identity according to who she was with. This statement is supported by Lima. She said:

This is not something that I experienced growing up. Those days we had to choose between being Maori or a Pacific Islander. The circumstance and who was asking determined which I chose. These days, with the influx of numerous diverse settlers, particularly to Auckland, there is more acceptance of difference - regardless of blend. However, at times, I feel that some Maori are not as accepting. For instance, I was privy to a speech recently by someone I respect. However, I was concerned about their comments that Maori are different to any other peoples in NZ and should be treated and respected that way. It transported me back to my growing up days and the pressure to determine which I was. I didn't have time to speak with the presenter and wondered if they realised that they were separating two peoples who are very connected by history and have an understanding. My experience in $N Z$ is that the Tangata whenua peoples are acknowledged and respected by 
Pacific people always. (Lima 2015, personal communication)

Sawicka et al. (2007) found in their study of young New Zealanders of Indian, Pākehā, Māori and Greek ancestry that their expressions of cultural identity varied depending on the situations they were in, that there were marked differences between what some saw as merely an ethnic label and what others saw as a living culture, and that for young Māori there was much variation in terms of alignment with 'traditional' markers of Māori identity (Sawicka et al., 2007). At certain times within both Ono and Lima's careers, they experienced racism, and this brought back the feelings of pressure to identify who they were going to be according to their community, family or environment. This was also supported by Fa's experience growing up. She says:

But in terms of me growing up, I didn't really know my Maori side, so I would never say I was Maori. I was actually ashamed because I never really knew anything about it, and my mum didn't really put that on me, it wasn't until I was older she reconnected with her culture, then she brought that down on me. When I was raised, I was brought up in a Sämoan community, and I never acknowledged my Maori side because my mum never made a point of it to me. At the time she was living with me and my Sämoan grandparents and she was trying to be respectful in terms of making them happy, so 
she would raise me as a Sämoan girl. It was only until I reached intermediate that I realised there were heaps of people of other cultures and that actually I wasn't the only Maori (laughs). Because in Primary everyone was either Sämoan, or Tokelauan or something but there was no Māori's, but then I went to intermediate that was joined with a collage so then I saw a whole lot of older kids and I was this little year 7 form 1, and there were heaps of different cultures, and it was fine. I was teased and mocked at Primary school by all my friends for being a Maori, but when I was surrounded by others in intermediate it didn't hurt me as much and I was ok with being Maori. I was like, ok but you're in my country so it was a cool way to retaliate, but growing up I was never taught any of that and never realised it. My whole family would acknowledge I was Maori, and be like come here you little Maori girl, everyone knew it, but because we lived with my grandparents everything was just Sämoan, speaking the language and doing things the Sämoan way. (Fa 2015, personal communication)

The participants were then asked 'Do you feel that a blended Pacific identity is acknowledged in your community? How?' They all had mixed responses, which were all positive, and they explained that a lot has changed and progressed over time, making blended identity more accepted in Aotearoa/New Zealand. In Lua's view: 
The pride of being acknowledged more in society of who my identity is has I think has been brought about by my children this generation, yells to the world who they are and where they are from and very proudly in school, work, social media (Facebook which I do not even try to use) every form of oral, visual concept. (Lua 2015, personal communication)

Lua recognises that change has occurred over time, and she sees this through her children, who proudly acknowledge their blended backgrounds. It is acknowledged through their schooling, work but most importantly social media. Over time social media has played a huge role with online communication channels dedicated to communitybased input, interaction, content-sharing and collaboration (Rouse, 2015). Lua adds that social media are oral and visual concepts that express her children's identity, and allow them to form wider connections of networks with family and friends. Lua uses Facebook as an example, but other forms of popular social media sites are Twitter, Instagram, Google+, Wikipedia, LinkedIn, Pinterest.

Lima speaks of her own experience being able to negotiate her identity depending on her situation. She said:

I believe I have become the expert of being at home, whatever the situation. It doesn't mean that I am not one identity or the other, but that 
one or other usually dominates depending on the situation. The change between them for me is seamless and very easy and gentle - on myself and those around me. I have often thought that I might pursue one identity and leave the others somewhere else-however, this hasn't been possible and I have come to realise that it isn't necessary and they are all special and contribute to the person I am - that is someone who is many parts and comfortable with this state of being. A gift that I am ever grateful for. (Lima 2015, personal communication)

At first I was a bit taken by Lima's response, and didn't feel comfortable knowing she changed her identity. I came to know that it was Lima's choice, and if anything it made her unique. Lima was able to negotiate her vā relations according to where she positioned herself in a certain situation. She used her blended background as her strength and came to know it as a gift she is grateful for.

Ono also expressed that she experienced the change of acceptance first-hand through her hapū. She said:

Throughout my lifetime I have experienced a change in societal attitudes. New Zealand Maori generally frowned upon intermarriage between New Zealand Māori and Pacific peoples in the 50s and 60s; and the same 
attitudes existed within Pacific communities as well. I was fortunate that within my hapu of Te Whānau a Ruataupare and the vision of our former leaders, strong relationships were forged between the Cook Islands and my hapü through the naming of our wharenui, Te Hono ki Rarotonga. Consequently, there has been intermarriage between members of the hapu and Cook Islanders and whakapapa is the evidence of this long-term relationship. (Ono 2015, personal communication)

For Ono, blended identity was becoming more acceptable through intermarriage, and the acknowledgments by her hapu of relations in the Cook Islands. Tasi, like Ono, also felt the recognition of blended Pacific identity is being realised, but only at its beginning stages. She states:

I feel the recognition of blended Pacific identity is only just starting to be realised. Before we were all just lumped into one culture or another. Often in the past when I was asked I would say I'm all of them and it would irritate me when I was told to choose one over the other because I was proud of both backgrounds just as I was proud to be the child of both parents not just one. (Tasi 2015, personal communication)

Tasi feels that we have still got a long way to go in recognising and acknowledging the diversity of Pacific peoples with blended backgrounds. In adding 
to this, Lua and Tolu also believed that although blended identity is recognised, this isn't acknowledged in their community. Lua said:

I have felt that there has been more of a changed view of blended identities only in my latter years of life. Growing up, everything was taught to us - 'doing things the Palagi way', therefore, sadly, we lost a lot of our heritage. I have always regretted not being able to learn either language, although I understand more Niuean than Sämoan, and also speak very little of Niuean language. (Lua 2015, personal communication)

Although Lua was affiliated more with her Niuean identity growing up, it was still considered very much the Palagi way of doing things. Lua acknowledges that, for her, language plays a major role in her Pacific identities, which she regrets not learning, but this also may have caused uneasy relationships with her Sāmoan identity, as language is one of the three poles founded within fa'asinomaga (Aiono, 1997), thus creating a vā. For Tolu, she feels no acknowledgment at all, although she claims she has not been compelled to investigate, and she too feels that knowing a Pacific language entitles you to more of an authentic Pacific identity. She states:

Unfortunately, as a Kiwi-born (Wellingtonian) I don't think we're really acknowledged. In 
relation to a blended Pacific identity - I haven't been compelled to investigate how we're acknowledged. I do feel that if we don't speak the language of any of our blended identity then we're not seen as 'authentic' or the 'real-deal'. We're 'Plasifika'. This is so annoying to me! (Tolu 2015, personal communication)

There was no real cohesion or theme that was shared between the participants to whether they thought blended identities were acknowledged in Aotearoa/New Zealand. Everyone had their own views and opinions according to their own experiences. The factors that influenced this vā, were the same factors that connected them to their main affiliated culture; these were: location, parents, elders in the family, church and language. Language, according to Lua and Tolu, played a huge factor in them being acknowledged as an 'authentic' Pacific Islander, and this is the case for most New Zealand-born Pacific youth.

\section{Part four: Space}

As expected, the concept of space in relation to their identity was a new concept for all participants. In this part of the talanoa, I began by explaining what I meant by this, and then opened up the discussion for questions. While this was the first time most had thought about their spaces in relation to their identity, most had reflected on the spaces they inhabit (home, work, office, church) and found it easy to see the relationship I was drawing on. They 
started to see spaces and objects that reflect their identity, and spoke about objects that reminded them of the Pacific Islands. Most of the participants were able to speak of several spaces that reflected their identity. Lima identified her family home, work, and her daily activities as spaces she connected to her identity. She said:

In my home, when I look in the mirror, when I have family gatherings, when I am cooking, when I am working, when I am shopping. I am very comfortable having a diverse background and no longer feel obliged to fit in with $N Z$ pakeha society and communities. I enjoy the freedom of living in a diverse city that is learning tolerance and to enjoy difference. Something that wasn't in existence when we were young. (Lima 2015, personal communication)

Lima identified spaces, but also beautifully described her physical appearance when looking in the mirror as a space that reminded her of her identity. This bold statement was her starting point, it was evident in her confidence that she was able to manifest her diverse identity in all that she inhabited. Her acceptance of who she was reflected in her freedom and ability to embrace the differences around her. Ono possessed this same confidence, although she was very brief in what she said, and spoke largely of her surroundings and spaces she decorated. 
In my home, in my research and supervision with postgraduate students which takes me to the Cooks and Hawai'i. (Ono 2015, personal communication)

Fa embraced her home, her Sāmoan husband and work environment as places she felt connected to her identity. She said:

Everywhere really, at home we're all Sāmoan my husband is Sämoan, at work I work for Pacific communities, even thou everyone at work calls me a Maori (laughs). I connect with a lot of my Pacific colleagues from managers, to team leaders and I love my job. (Fa 2015, personal communication)

Lua summarises nicely in a few words the impression I got from Lima, Ono and Fa that 'There is no gap/gaps'. That identity for these participants wasn't seen as separate components of islands, culture, and traditions, it was a merging of these what they embraced as their identity. Lua said:

There is no gap/gaps. I am Pasifika. My values and learnings are from my Mother and this is instilled to my children on every level at every point. For me, there is no such thing as a point or time in my daily life in feeling most connected to my identity. (Lua 2015, personal communication) 
Lua's upbringing and Pacific cultural teachings from her mother, have also been passed down to her children. For Lua there is no point in time or place where her identity lies, it is very much who she is as a Pacific woman.

Unlike the others Tasi felt a reconnection to her identity when returning to Postgraduate study as a mature student. She said:

Since returning to do postgraduate study, I am starting to feel reconnected to my identity because in finding answers to my research question I am reconnecting with extended family I have not seen since I was young and being reintroduced reminds me of the identities I had put on a shelf and had forgotten for some time. I don't wear it loud and proud but more a quiet pride on the inside. (Tasi 2015, personal communication)

Tasi's response was humbling as her postgraduate study took her on a journey that would reconnect her with parts of her identity she had forgotten about. Her identity is very much reflected in her artistic ability and research, but not so much in the spaces she inhabits.

Their responses to the questions taught me that over time, they became more comfortable expressing their identities. All participants except Tasi, had 
come to realise that their daily living was a reflection of their identity, not just a singular space, but 'everywhere'.

\section{Photographs Documentation of Blended Spaces}

This article concludes with photos of the spaces described by each participant, these selected images are accompanied by their anonymous voices and personal insight into their identities.

I have different living experiences that reflect many things - one home is very special and holds the history and memories of five generations of our family. There are smells, imprints, photos, memories that surround me when I am in the old house. Far from a museum, the old house is a safe haven, not just for me, but for the ever-expanding extended family that love to visit, hear the old family stories, see the history and feel part of it all. 

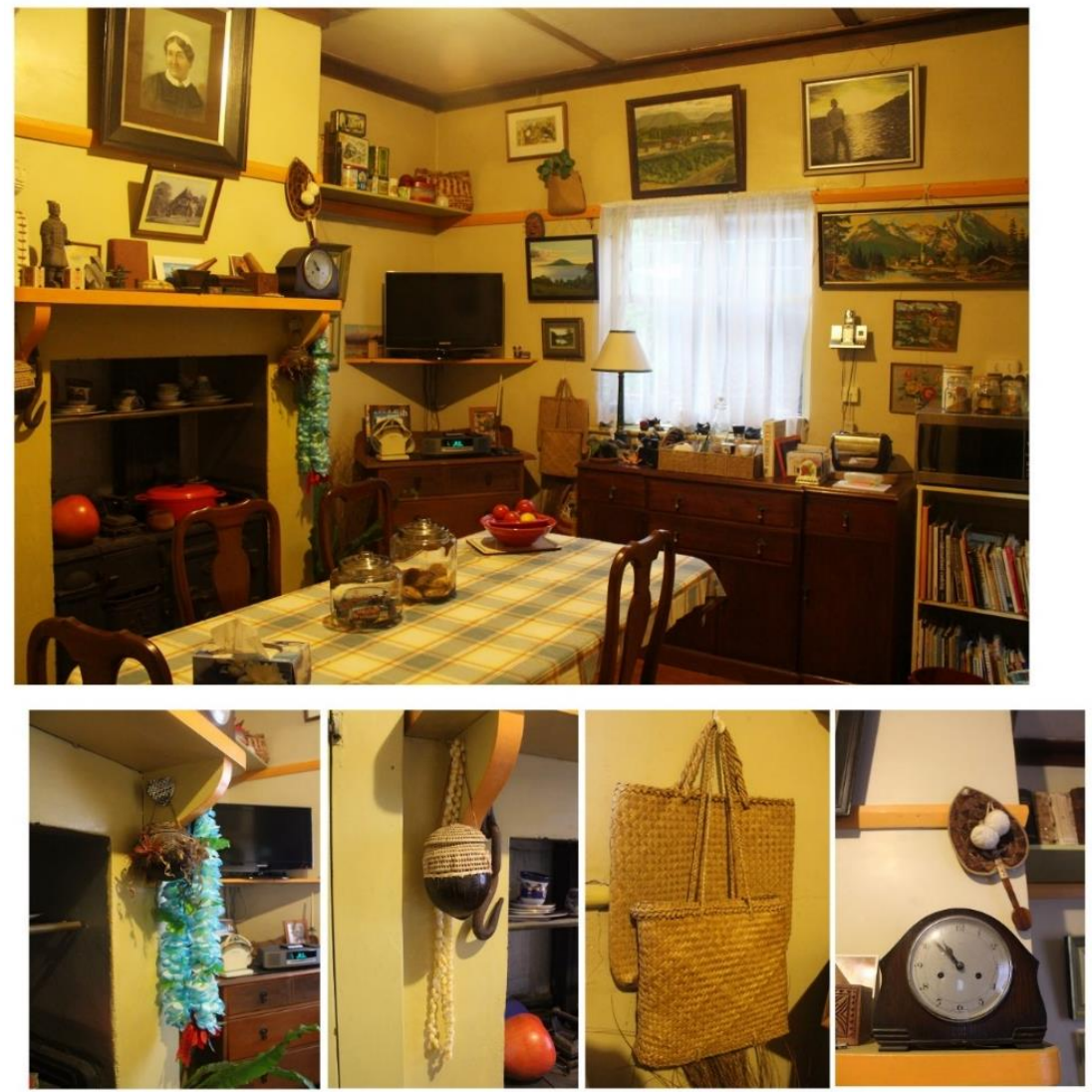

The garden is a reflection of my grandparents old trees planted by them - fertile soil, which my grandfather utilised every square inch to help feed his family, neighbours and friends. I love occasionally finding 'things' deep in the soil that 
belonged to the family - old bottles, gardening equipment. I curse the old Holly Tree that grandmother planted so many many years ago. Sometimes, barefooted, I step on the prickly leaves - ouch. When I fire up the old coal range, I think of my grandparents and their lives back in the early 1900s.

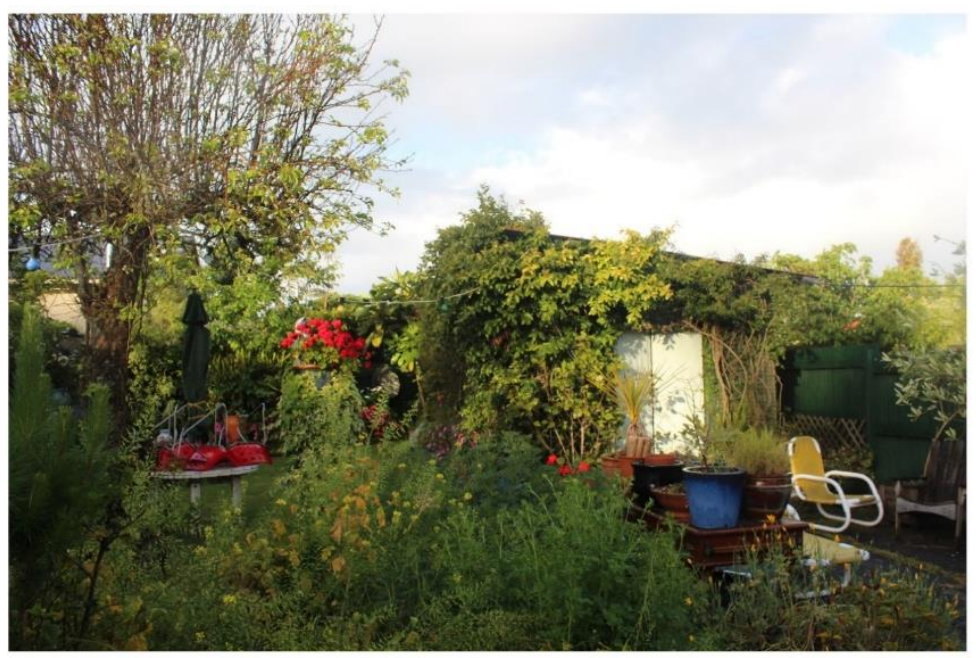

I was born into a home where beads, carvings, photos were everywhere, I loved the items my mum would display around the house, you just don't get that anymore. We were part of the new suburbia that developed in the 60s in NZ. Nuclear families (which I hated - I missed my Aunties and Uncles that I had around me for the first 5 years of my life 

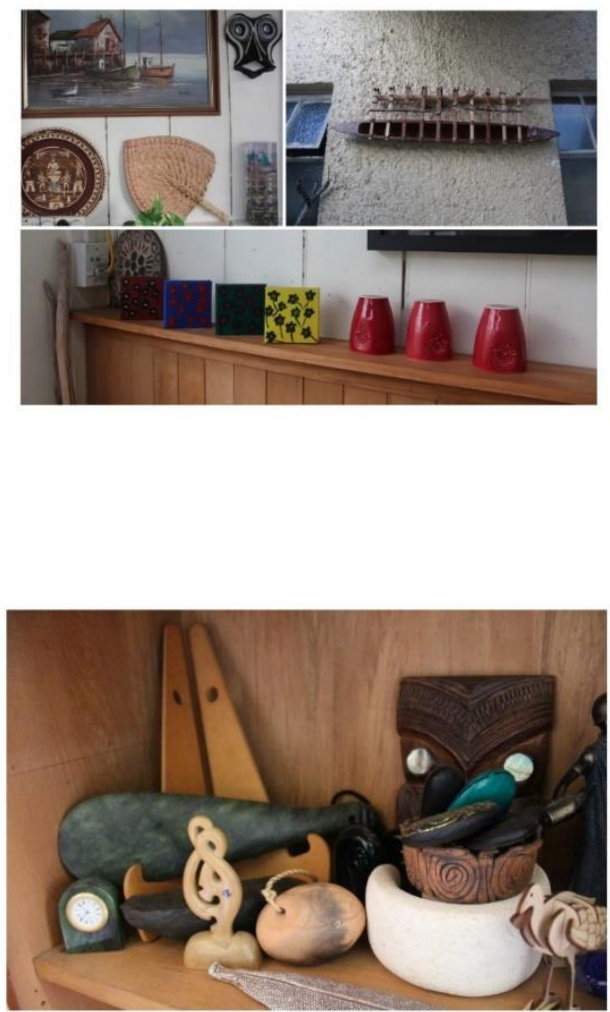

My homes today - reflect many parts of me and I am privileged to have the luxury of them being separate, rather than trying to blend them all together. It means that I get to be that part of 
me completely depending on where I am. One day, I will need to work out how to bring it together as I won't be able to live so separately

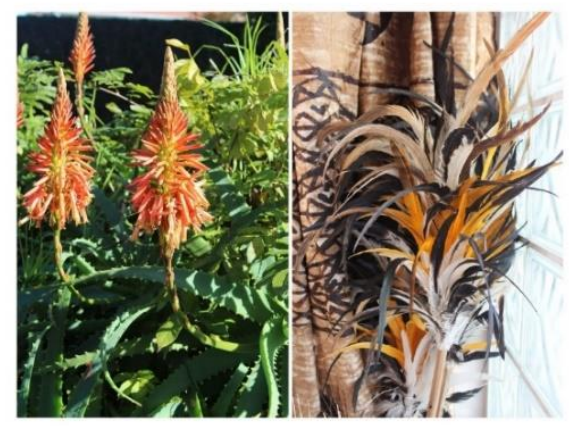

I feel most connected with my culture at home, because I have my sister with me who brings the Maori culture into my life, and every day now, and she teaches me heaps of Maori words. And living with my Nana who only speaks Sāmoan, so having that language around me constantly is precious to me, and makes my cultural identity. Defiantly at home where we are all connecting and engaging with each other. 

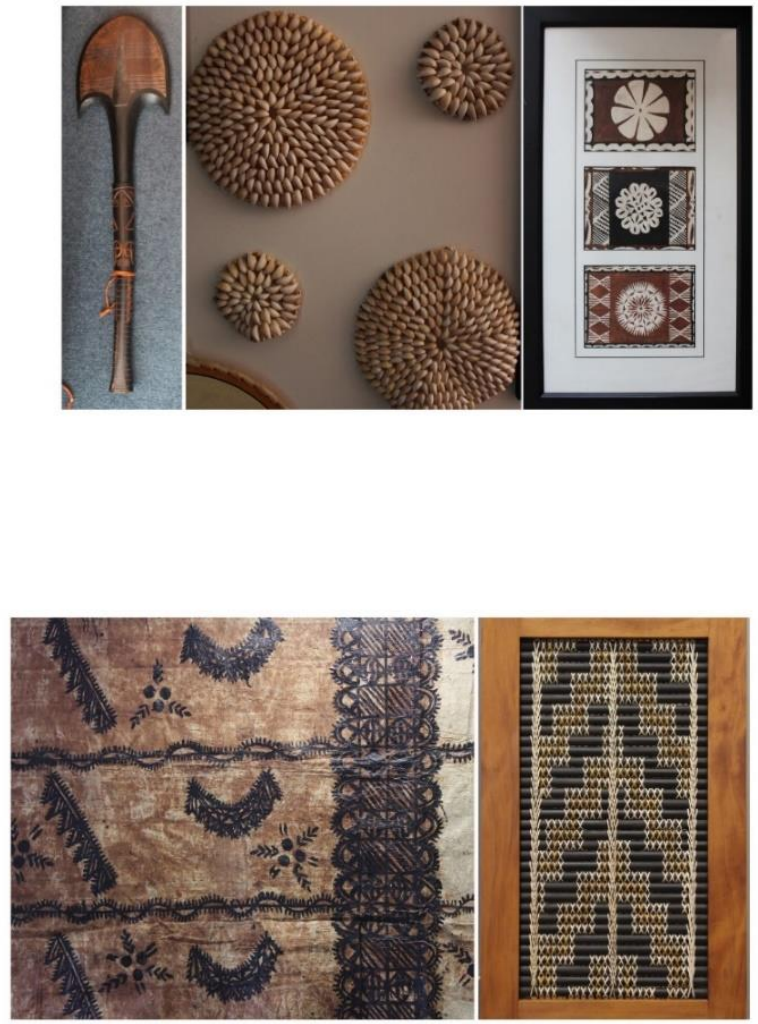

Come to our home, and you can from a visual perspective, of my identity, see the love of Pasifika. The brightness of colour, richness of food, music of singing, vibrancy of art, design of 
dress...everything is Pasifika - it's the language that there is little of, but not for want of trying...I practise all the time.

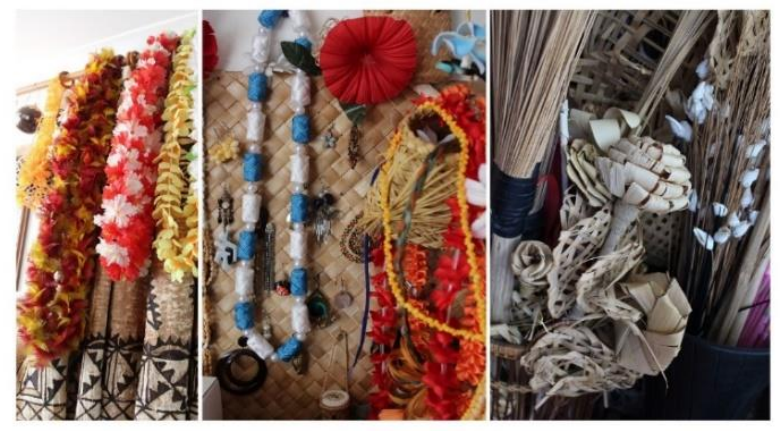

The strength of family has never diminished from growing up and to what I have imparted to our children. The love and support from family towards each other, the basic family values of courtesy and manners is always at the forefront. Not having much is called improvising - no such thing as 'going without.' Our houses were very different in structure and location, but our home has always been filled with love and caring, which is the only thing that matters. 


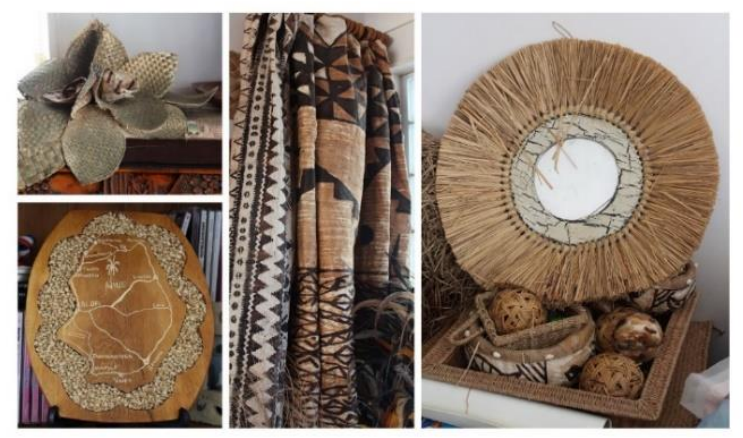

My home/ furniture/ garden/ art reflects my blended identity! Of course in the food we eat, in the jewellery I have; in the family artifacts that adorn our home like, the Hawaiian quilts and tivaevae from the Cooks on the room table; the framed art on the walls; the frangipani and gardenia in the outside gardens and moth orchids and anthodium's inside; the scent of ecoya candles; the koa wood panel; the ukelele's; the Hawaiian signage; the numerous CDS of Pacific musicians, etc 

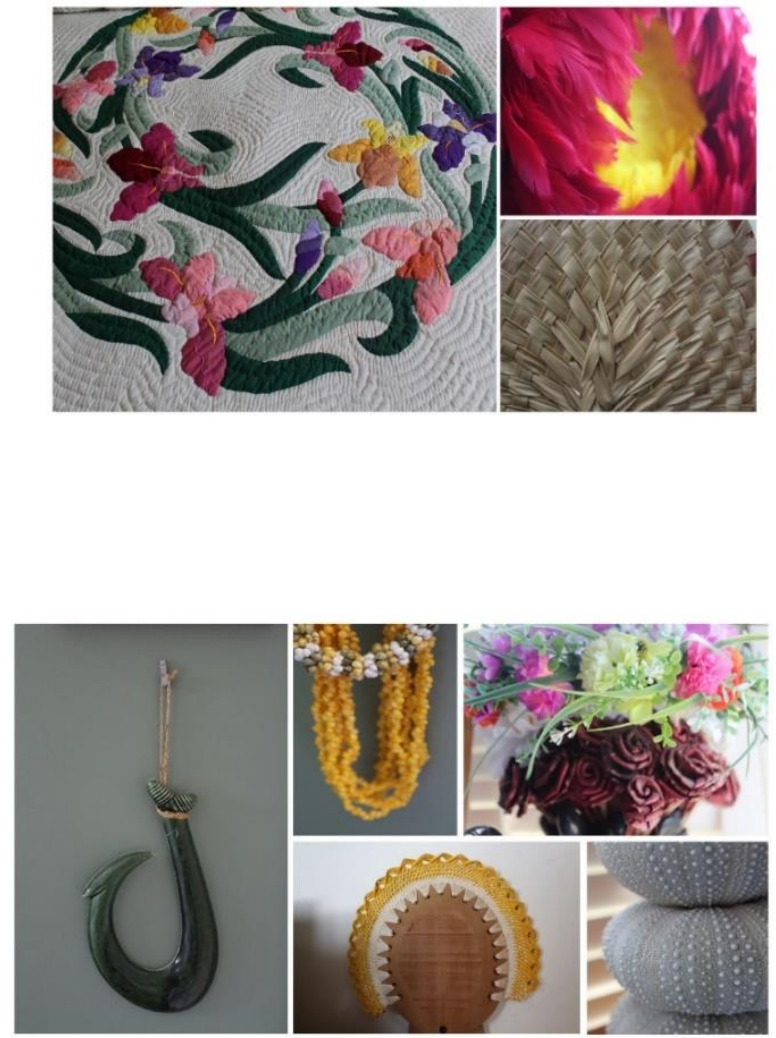

The most poignant comparison between my home as a child and my home now is the absence of elders from my Cook 
Island/Sāmoan / Hawaiian and Māori families. I was fortunate to have been brought up with grandparents and great grandparents who had significant influence on my life.

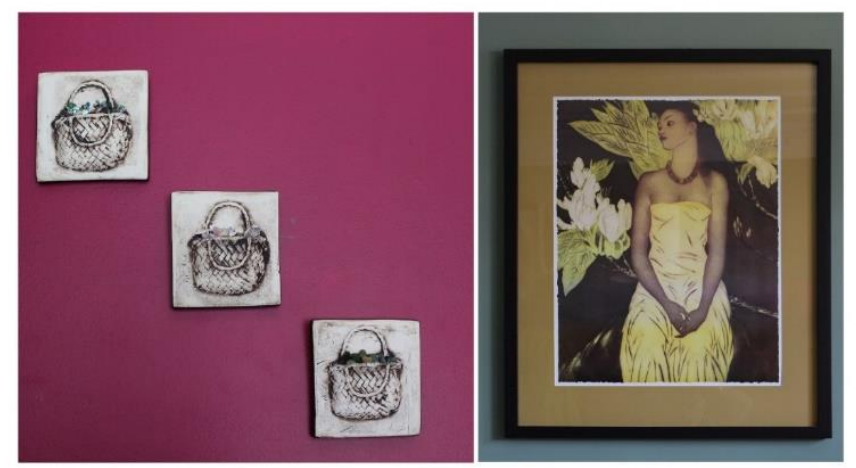

The home I live in now, is quite empty and undecorated in comparison to the home I grew up in. I grew up in a house that had cultural wall hangings, religious paintings and family portraits with plastic flowers around them. We had a woven mat on the sitting room floor and my mum did a lot of embroidery which was on our pillow slips and other items. We also had crocheted blankets and I remember one brightly coloured tivaevae blanket that was used on my parent's bed too. My mother did a lot of craft which she had learnt as a child in Tonga, both 
she and my father were keen on gardening so we had taro leaves growing out back and in the front, our garden looked like a decorative Tongan garden of the monarchy with neat rocks surrounding flower beds and so on.

\section{Discussion}

During the process of taking photos in the home of Lua, our talanoa continued as she weaved her way through her beautiful home narrating stories about certain pieces, and she asked me about the security of her tapa cloth and fine mats. I was curious to find out what she had meant by this, and she went on to explain how a few pieces of her tapa collection had suffered water damaged from a house flood earlier that year. The concern in her voice was because these particular tapas were unique and special to her; they had been in her family for generations and were then gifted to Lua as a wedding gift, and she had planned on gifting these to her daughters when they got married. I then respectfully asked Lua if I could view the damage, and she was more than happy to bring them into work for me to see the tapa.

These tapa cloths have been in my family for generations, and I am just heart broken, that I didn't realise the water from upstairs and soaked through the ceiling and was leaking straight onto my previous tapa. It was only months later when I was going through my tapa to air it out, that I found out what had happened 
and it was too late to do anything. But other issue was with my claim for insurance, I know it can't be fixed, I just wanted it value in money so I could possibly buy another one to replace it. But I don't know how much these things cost, or how much I'm entitled to, could you help me Benita? (Lua 2015, personal communication)

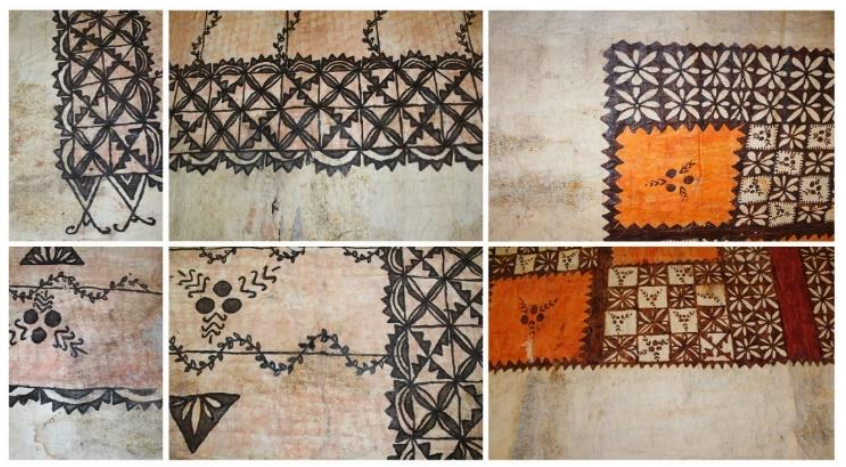

She had mentioned she had house insurance, but didn't know the value of her tapa, or how to seek this sort of advice from an expert. By this time, I was eager to help my participant, so I sought help from my connections in the community, and they too were unsure of the value of the tapa in monetary terms. I then asked an elder from our church community, and with her knowledge and expertise in making the tapa and my historical knowledge 
about the tapa, we were able to value the tapa. I then went away to write up a letter for Lua explaining how we justified the value and authenticity of the tapa, for her insurance claim. Lua was very grateful and was successful in receiving her claim.

Lua was one person who I had the pleasure of helping, and our talanoa together raised many issues for me regarding the preservation of Pacific artefacts in the diaspora. This was a beautiful piece of history that pertained to Lua's family and it was a shame to have lost the mana (authority, power, prestige) this tapa carried. At the same time, I knew this particular story was an example of what I was hoping to gain from my talanoa with participants. This was not just a journey Lua had travelled alone; many others in the diaspora shared this same experience. It raised questions for me around issues of preservation, and what happens to the masses of artefacts that are damaged, lose recognition and disappear without proper care. Reflecting on the photos I had taken from all of my participants, it was amazing to see the historical pieces collected and treasured in each home, which showed that it wasn't the spatial environment that was important, but rather the artefacts that adorned these blended spaces. Pacific artefacts that have travelled from all around the Pacific Islands and have their own significant history and meaning to each family. These were the very images I wanted to archive and expected to exhibit for my final examination, that is, these blended spaces of identity. The spaces of our 
future generations is something to celebrate and be a part of. Yet something in my heart didn't sit right for the conclusion of this research. Something more was stewing in my head.

I wanted to contribute to my community in more ways than one, to give back to my participants and show them the alofa (love) I was given when I visited each of them, and to acknowledge each Pacific Island individually and its significance to our blended identity in the diaspora. I also wanted to capture other beautiful Pacific artefacts in the diaspora that pertained traditional skills and significant history. To acknowledge the blended Pacific communities in the diaspora. To create a blended Pacific community in the wider diaspora. To create an archival repository shedding light of Pacific craftsmanship. To create a space for blended identities to feel safe learning about their different identities, cultures and traditions. So how were my skills as a spatial designer going to achieve all of these goals?

An archival digital repository of Pacific artefacts from the diaspora community was my solution. This was to be the creative component of my research, specifically an archival system built for the sole purpose of preserving the knowledges, traditions and history contained in Pacific artefacts from the diaspora. This has long been a dream of mine to create something I could gift to my community and be proud of achieving. Having now discussed 
significant talanoa with the research participants, it is useful to examine the Lala-Vā methodology and its application to the project design. 


\section{References}

Sawicka, T., Barr, K., Grace, D., Grenside, L., Thomson, J., \& Williams, G. (2007). Forming a cultural identity: What does it mean to be ethnic: Retrieved.

Spickard, P. R., Rondilla, J. L., \& Hippolite Wright, D. (2002). Pacific diaspora: island peoples in the United States and across the Pacific. Honolulu: University of Hawai'i Press.

Spoonley, P. (2000). Reinventing Polynesia: The cultural politics of transnational Pacific communities: University of Oxford. Transnational Communities Programme. 